\title{
Environmental Impact Assessment of Boga Bridge Patukhali
}

\author{
M. H. Islam*, M. Faisal and K. A. Mahmood \\ Faculty of Disaster Management, \\ Patuakhali Science and Technology University, Patuakhali \\ *Corresponding author: hamidcekuet@gmail.com
}

\begin{abstract}
The economic development and social unity largely depend on the communication facilities. Improvement of national highway network in Bangladesh has been obstructed due to some rivers. Lohalia is one of the largest rivers in Patuakhali district divides Bauphal and Dumki upazila. The major transport barrier between the Bauphal and Patuakhali, Barisal city is Boga Bridge. The proposed 900 meter long Boga Bridge will be constructed under the supervision of World Bank, ADB, local and international experts. This paper shows the environmental impact assessment of Boga Bridge over the Lohalia River. The aim of the study is to identify the major environmental impact, mitigation measures and environmental impact value of the Boga Bridge. The major impacts of the Boga Bridge are loss of livelihood, loss of land, delta formation, loss of trees and rare species, loss of fisheries, navigational restrictions, surface water pollution, air pollution, soil contamination, river bank erosion, change the river flow. The environmental impact value of this project is "- 3 " (negative three). The mitigation measures for the Boga Bridge project are cash compensation, relocation, periodic dredging, plant two for one felled, provide new jobs, revetment, provide safe water, good food and sanitation etc. By the proper implementation of these mitigation measures must help to reduce these impacts.
\end{abstract}

Key words: Bridge project, Environmental impact value, Mitigation

\section{Introduction}

Coastal part of a country is always important for the country development. The main reason behind this is the plentiful resources and livelihood opportunity. But in the case of Bangladesh, its coastal part remains deprived. The main reason behind this is the lack of standard communication facilities in coastal parts. For this it needs to develop this part very early by developing communication facilities through constructing bridges, culverts, roads etc. (Kundu, 2011). The economic development and social unity largely depend on the communication facilities. Improvement of national highway network in Bangladesh has been obstructed due to some rivers. Boga is one of the largest rivers in Patuakhali district divides Bauphal and Dumkiupazila. The major transport barrier between the Bauphal and Patuakhali, Barisal city is Boga Bridge. The river poses an impediment to economic development and social integrity between these two parts. There has long been desire to improve the transportation network and the energy transfer to the Bauphal Upazila. By thinking of this, we recognized a river which should have a bridge as this is one of the important place for trade. The proposed project is constructing of Boga Bridge. So for the development of this area it needs to construct a bridge urgently.

EIA is the systematic process of identifying the future consequences of a current or proposed action (Huq, 2002; Krishnamoorthy, 2005; BBA, 2010; Kundu, 2011). This report produces for the evaluation of the Environmental Impact Assessment of the Proposed Boga Bridge. The objectives of the study are- to identify the impacts, and mitigation of the Boga Bridge project, and to calculate the environmental impact value.

\section{Materials and Methods}

Information concerning the EIA of the project is mainly based on the available secondary and primary data. The secondary data pertaining to the study were collected from different sources like Bangladesh Water Development Board (BWDB), Local Government Engineering Department (LGED), Bangladesh Agriculture Development Corporation (BADC), Department of Roads and Highway (RHD), Department of Public Health Engineering (DPHE), Department of Land Record Survey (DLRS) and primary data was collected from Local Chairmen and Members of the Union Boga, Local elites of the project area and Focus Group Discussion with local people. The environmental impact value is calculated by the equation (Wilson, 1998; Saha, 2007):

$$
E I V=\sum_{i=1}^{n}(V i) w i
$$

where, EIV = Environmental Impact Value, $\mathrm{Vi}=$ Relative change of the environmental quality of parameters, $\mathrm{Wi}=$ Relative importance or weight or parameter, $\mathrm{N}=$ total number of environmental parameters.

Changes of environmental parameters are severe $(+5$ or -5$)$, higher $(+4$ or -4$)$, moderate $(+3$ or -3$)$, low $(+2$ or -2$)$, very Low $(+1$ or -1$)$, no change $(0)$.

\section{Study area}

The project area is located in the southern coastal part of Bangladesh. The project area comprises Boga union in Bauphal upazila in the East bank of Boga River and Muradia union in Dumki upazila on its West bank. The cities, namely Patuakhali and Barisal are located at the distance of $22 \mathrm{~km}$ and 40 $\mathrm{km}$ respectively from the Boga Bridge. The objective of the Project is to support economic growth and poverty reduction through improved connectivity between Bauphal upazila and other 
regions in Bangladesh by achieving the smoother transportation. The Boga bridge project includes the following components: the main bridge (Boga Bridge), the bridge end facilities at the east and west bank of Boga River, the approach road connecting the bridge with national highway and the river training works.

\section{Results and Discussion Environmental impact and mitigation}

The Boga Bridge project has many potential environmental impacts; from them some major potential environmental impacts and its mitigations are given bellow (Tables 1, 2, 3).

Table 1. Environmental impact and mitigation measures of pre-construction stage

\begin{tabular}{|c|c|c|c|}
\hline & $\begin{array}{l}\text { Environmental } \\
\text { Components }\end{array}$ & Potential Impacts & $\begin{array}{l}\text { Mitigation } \\
\text { Measures }\end{array}$ \\
\hline \multirow{3}{*}{ Ecological Environment } & $\begin{array}{l}\text { Movement of survey team and } \\
\text { project staff }\end{array}$ & Loss of field crops & Avoid disturbance \\
\hline & Tree felling & Impact on ecology & Cash compensation \\
\hline & Disturbance to wildlife & Wildlife migration & Minimization of noise \\
\hline \multirow{4}{*}{$\begin{array}{l}\text { Socio economic } \\
\text { Condition }\end{array}$} & $\begin{array}{l}\text { Apprehended loss of ancestral } \\
\text { homes/ lands and properties. }\end{array}$ & Psychological stress & Inform the real Situation \\
\hline & Apprehended loss of livelihood & Psychological stress & Inform the actual Situation \\
\hline & Cultural Resources & Loss of cultural resources & Relocate if inevitable \\
\hline & Privacy loss & Movement of team & Avoid disturbance \\
\hline
\end{tabular}

Table 2. Environmental impact and mitigation measures of construction stage

\begin{tabular}{|c|c|c|c|}
\hline & $\begin{array}{l}\text { Environmental } \\
\text { Components }\end{array}$ & Potential Impacts & $\begin{array}{l}\text { Mitigation } \\
\text { Measures } \\
\end{array}$ \\
\hline \multirow{5}{*}{ Natural resources } & Loss of land & $\begin{array}{l}\text { Loss of livelihood Reduced food } \\
\text { production }\end{array}$ & $\begin{array}{l}\text { Cash compensation/ } \\
\text { Relocation on Khas land }\end{array}$ \\
\hline & Hydrology/Flood pattern & $\begin{array}{l}\text { Approach roads might Impact on } \\
\text { Hydrology }\end{array}$ & $\begin{array}{l}\text { Adequate clearance on } \\
\text { Embankment }\end{array}$ \\
\hline & Drainage congestion & May cause drainage congestion & $\begin{array}{l}\text { Adequate openings on } \\
\text { Embankment }\end{array}$ \\
\hline & Erosion/Sedimentation & $\begin{array}{l}\text { Piers might create } \\
\text { Water head difference }\end{array}$ & $\begin{array}{l}\text { Bogha a tidal river carries } \\
\text { small volume of sediment } \\
\text { load }\end{array}$ \\
\hline & Delta formation & $\begin{array}{l}\text { Delta formation may Induced at } \\
\text { Piers sites }\end{array}$ & Periodic dredging \\
\hline \multirow{5}{*}{ Ecological resources } & Loss of agriculture & Loss of agriculture land & Cash compensation \\
\hline & Loss of trees & Impacts ecology and Economy & $\begin{array}{l}\text { Cash compensation } \\
\text { Plant two for one felled }\end{array}$ \\
\hline & Loss of fisheries & $\begin{array}{l}\text { Fishing may be affected in Bogha } \\
\text { River }\end{array}$ & Cash compensation \\
\hline & Wetland & Wetlands may be affected & $\begin{array}{l}\text { Avoid wetlands, Cash } \\
\text { compensation, dig }\end{array}$ \\
\hline & Wildlife & $\begin{array}{l}\text { Wildlife might migrate due to } \\
\text { noise }\end{array}$ & $\begin{array}{l}\text { Wildlife will return after } \\
\text { construction is completed }\end{array}$ \\
\hline \multirow{5}{*}{$\begin{array}{l}\text { Socio economic } \\
\text { Resources }\end{array}$} & Loss of income & Jobs at ferry ghat may be lost & $\begin{array}{l}\text { Cash compensation, Provide } \\
\text { of jobs }\end{array}$ \\
\hline & Cultural resource loss & Nothing apprehended & $\begin{array}{l}\text { Cash compensation } \\
\text { Relocation }\end{array}$ \\
\hline & $\begin{array}{l}\text { Navigational } \\
\text { restrictions }\end{array}$ & $\begin{array}{l}\text { May create hindrance to } \\
\text { navigation }\end{array}$ & $\begin{array}{l}\text { Compensation, to maintain } \\
\text { navigational clearance }\end{array}$ \\
\hline & Public health safety & $\begin{array}{l}\text { Workers in camps might pose } \\
\text { public health risk }\end{array}$ & $\begin{array}{l}\text { Provide safe water, good food } \\
\text { and sanitation }\end{array}$ \\
\hline & Occupational Health safety & $\begin{array}{l}\text { Workers may meet accidents } \\
\text { during works }\end{array}$ & $\begin{array}{l}\text { Periodic health Checkup and } \\
\text { vaccination }\end{array}$ \\
\hline & Employments & $\begin{array}{l}\text { Loss of many jobs and create few } \\
\text { jobs }\end{array}$ & $\begin{array}{l}\text { Employ the PAP's in project } \\
\text { jobs. }\end{array}$ \\
\hline & Women empowerment & $\begin{array}{l}\text { Will facilitate women } \\
\text { empowerment, Creating jobs for } \\
\text { them }\end{array}$ & Maintain gender equity \\
\hline & Road accidents & $\begin{array}{l}\text { Movement of transports faster } \\
\text { may cause road accidents }\end{array}$ & $\begin{array}{l}\text { Enforce the traffic rules, } \\
\text { Maintenance of the } \\
\text { Automobiles and road }\end{array}$ \\
\hline \multirow[t]{2}{*}{ Chemical pollution } & Surface water pollution & $\begin{array}{l}\text { Water at camp site may be } \\
\text { polluted by disposals of solid } \\
\text { wastes, faecal } \\
\text { contaminants, and noxious } \\
\text { chemicals }\end{array}$ & $\begin{array}{l}\text { Avoid wastes, cement, } \\
\text { Bentonite, chemicals, etc. } \\
\text { disposal in water }\end{array}$ \\
\hline & Air Pollution & $\begin{array}{l}\text { Emission of SOx, NOx, COx } \\
\text { gases from vehicles, plants, etc. }\end{array}$ & $\begin{array}{l}\text { Operate construction plants, } \\
\text { vehicles properly. Install }\end{array}$ \\
\hline
\end{tabular}




\begin{tabular}{|c|c|c|c|}
\hline & & $\begin{array}{l}\text { and dust, dirt, smoke from work } \\
\text { sites }\end{array}$ & $\begin{array}{l}\text { plants at safe distance from } \\
\text { Locality }\end{array}$ \\
\hline & Soil Contamination & $\begin{array}{l}\text { Soil Quality may be affected due } \\
\text { to solid wastes disposal and } \\
\text { spillage of noxious contaminants }\end{array}$ & $\begin{array}{l}\text { Avoid disposing solid wastes } \\
\text { on soil, store, transport, } \\
\text { handle noxious materials } \\
\text { carefully }\end{array}$ \\
\hline & Noise Pollution & $\begin{array}{l}\text { Movement of vehicles, operation } \\
\text { of ballast, concrete mixing, other } \\
\text { plants, generator cause sound } \\
\text { pollution }\end{array}$ & $\begin{array}{l}\text { Maintain all plants, vehicles, } \\
\text { machineries properly. Install } \\
\text { plants be at safe distance. } \\
\text { Operation time is chosen }\end{array}$ \\
\hline & $\begin{array}{l}\text { Works with cement and } \\
\text { concrete }\end{array}$ & $\begin{array}{l}\text { Cement is toxic for fish, plant and } \\
\text { animal. }\end{array}$ & $\begin{array}{l}\text { Cement work sites to be far } \\
\text { from open water bodies. } \\
\text { Avoid water pollution by } \\
\text { concrete } \\
\text { washout. }\end{array}$ \\
\hline & $\begin{array}{l}\text { Contamination by oil and } \\
\text { chemicals } \\
\text { spillage }\end{array}$ & $\begin{array}{l}\text { Contamination may be due to oil, } \\
\text { chemicals and organic wastes }\end{array}$ & $\begin{array}{l}\text { Works with contaminants be } \\
\text { carried out away from open } \\
\text { water bodies }\end{array}$ \\
\hline \multirow{4}{*}{ Accidents } & Working at heights & $\begin{array}{l}\text { Fall from high place causes injury } \\
\text { even death }\end{array}$ & $\begin{array}{l}\text { Can be reduced using PPEs, } \\
\text { and with due protection } \\
\text { training }\end{array}$ \\
\hline & Working on/near water bodies & $\begin{array}{l}\text { Drowning incidents occur due to } \\
\text { lack of safety measures }\end{array}$ & $\begin{array}{l}\text { Use lifebelt during work time, } \\
\text { avoid working on water } \\
\text { bodies alone }\end{array}$ \\
\hline & $\begin{array}{l}\text { Working with electric } \\
\text { machineries }\end{array}$ & $\begin{array}{l}\text { Cutting and grinding machines, } \\
\text { gears, chain drives, fans etc. may } \\
\text { cause lethal accidents }\end{array}$ & $\begin{array}{l}\text { Use safe guards to the plants. } \\
\text { Protect workers from contacts } \\
\text { of moving machineries }\end{array}$ \\
\hline & Accidents at work sites & $\begin{array}{l}\text { On lookers out of curiosity may } \\
\text { enter the work sites or pass across } \\
\text { the work sites }\end{array}$ & $\begin{array}{l}\text { Construct temporary fence } \\
\text { around the work sites and post } \\
\text { security guards }\end{array}$ \\
\hline
\end{tabular}

Table 3. Environmental impact and mitigation measures of operation stage

\begin{tabular}{|c|c|c|c|}
\hline \multirow{3}{*}{ Physical resources } & Hydrology and flooding & $\begin{array}{l}\text { Bridge induced Obstacles may not } \\
\text { impact river hydrology }\end{array}$ & $\begin{array}{l}\text { Changed hydrology can be } \\
\text { corrected by RTW }\end{array}$ \\
\hline & Drainage congestion & $\begin{array}{l}\text { Congestion may be caused by approach } \\
\text { roads }\end{array}$ & Create adequate opening \\
\hline & River bank Erosion & $\begin{array}{l}\text { Lebukhali River shows signs of bank } \\
\text { erosion }\end{array}$ & $\begin{array}{l}\text { RTW will reduce risk of bank } \\
\text { erosion. }\end{array}$ \\
\hline \multirow{3}{*}{ Ecological resources } & $\begin{array}{l}\text { Tree planting on } \\
\text { approach road sides }\end{array}$ & $\begin{array}{l}\text { Trees on approach road sides and } \\
\text { distribution of tree seedlings will have } \\
\text { positive impact. }\end{array}$ & Enhancement \\
\hline & Agriculture & $\begin{array}{l}\text { Safe and fast road communication will } \\
\text { cast positive impacts on agriculture }\end{array}$ & Enhancement \\
\hline & Wildlife & $\begin{array}{l}\text { Restoration of environment due to road } \\
\text { side tree planting will favor wildlife to } \\
\text { return }\end{array}$ & Enhancement \\
\hline \multirow{2}{*}{ Chemical pollution } & Air Pollution & $\begin{array}{l}\text { Movement of land transports will pollute } \\
\text { air due to emissions and blowing of dust } \\
\text { and dirt }\end{array}$ & $\begin{array}{l}\text { Maintain vehicles properly } \\
\text { and roads clean }\end{array}$ \\
\hline & Noise and vibration & $\begin{array}{l}\text { Project site and command area will be } \\
\text { noisy because of movement of larger } \\
\text { numbers of vehicles }\end{array}$ & Maintain the vehicle properly \\
\hline \multirow{3}{*}{$\begin{array}{l}\text { Socioeconomic } \\
\text { Condition }\end{array}$} & Road accidents & $\begin{array}{l}\text { Number of death and injury due to road } \\
\text { accident will rise }\end{array}$ & $\begin{array}{l}\text { Proper maintenance of road, } \\
\text { vehicles and strict compliance } \\
\text { to traffic rules }\end{array}$ \\
\hline & Health and sanitation & $\begin{array}{l}\text { Heath and sanitation conditions at } \\
\text { project command area will improve due } \\
\text { to induced urbanization rate }\end{array}$ & $\begin{array}{l}\text { Sporadic growth of shops and } \\
\text { shanties on approach roads } \\
\text { should be checked }\end{array}$ \\
\hline & $\begin{array}{l}\text { Employment } \\
\text { opportunities }\end{array}$ & $\begin{array}{l}\text { Augment work opportunities in the } \\
\text { region }\end{array}$ & Enhancement \\
\hline
\end{tabular}

\section{Calculation of environmental impact value}

Environmental impact value is the actual value of impact on the environment. Environmental impact value consists of three assessment of impact, they are: ecological impact, physicochemical impact and impact on human interest. By using the equation no... (i) Calculation of Environmental Impact Value of Boga Bridge is given below. 
Table 4. Estimation of ecological impact value

\begin{tabular}{|l|c|c|c|}
\hline \multicolumn{1}{|c|}{ Impact on } & $\begin{array}{c}\text { Relative } \\
\text { Impact } \\
\text { Value }\end{array}$ & $\begin{array}{c}\text { Degree } \\
\text { of } \\
\text { impact }\end{array}$ & $\begin{array}{c}\text { Individual } \\
\text { Environmental } \\
\text { Impact Value }\end{array}$ \\
\hline Fisheries & 25 & -2 & -50 \\
\hline Forest & 5 & -1 & -5 \\
\hline Roadside plantation & 10 & +2 & +20 \\
\hline Wetland habitat & 10 & 0 & 0 \\
\hline Air pollution & 6 & -1 & -6 \\
\hline Water pollution & 8 & -1 & -8 \\
\hline Sound pollution & 9 & -1 & -9 \\
\hline Soil pollution & 5 & -1 & -5 \\
\hline Ecosystem & 15 & -1 & -15 \\
\hline $\begin{array}{l}\text { Extinction of } \\
\text { different species }\end{array}$ & 7 & -3 & -21 \\
\hline Total & & & $\mathbf{- 9 9}$ \\
\hline
\end{tabular}

Table 5. Estimation of physicochemical impact value

\begin{tabular}{|l|c|c|c|}
\hline \multicolumn{1}{|c|}{ Impact on } & $\begin{array}{c}\text { Relative } \\
\text { Impact } \\
\text { Value }\end{array}$ & $\begin{array}{c}\text { Degree } \\
\text { of } \\
\text { impact }\end{array}$ & $\begin{array}{c}\text { Individual } \\
\text { Environmental } \\
\text { Impact Value }\end{array}$ \\
\hline Erosion & 15 & -3 & -45 \\
\hline Drainage congestion & 5 & -2 & -10 \\
\hline Water logging & 15 & 0 & 0 \\
\hline Flooding & 10 & -1 & -10 \\
\hline Salinity intrusion & 12 & -1 & -12 \\
\hline Waste generation & 8 & -1 & -8 \\
\hline $\begin{array}{l}\text { Change the river } \\
\text { flow }\end{array}$ & 10 & -2 & -20 \\
\hline Siltation & 10 & -3 & -30 \\
\hline Dust pollution & 10 & -1 & -10 \\
\hline $\begin{array}{l}\text { Obstruct of normal } \\
\text { water flow }\end{array}$ & 5 & -1 & -5 \\
\hline Total & & & $\mathbf{- 1 5 0}$ \\
\hline
\end{tabular}

Table 6. Estimation of human interest impact value

\begin{tabular}{|l|c|c|c|}
\hline \multicolumn{1}{|c|}{ Impact on } & $\begin{array}{c}\text { Relative } \\
\text { Impact } \\
\text { Value }\end{array}$ & $\begin{array}{c}\text { Degre } \\
\text { e of } \\
\text { impact }\end{array}$ & $\begin{array}{c}\text { Individual } \\
\text { Environmental } \\
\text { Impact Value }\end{array}$ \\
\hline $\begin{array}{l}\text { Loss of agricultural } \\
\text { land }\end{array}$ & 10 & -2 & -20 \\
\hline $\begin{array}{l}\text { Generation of } \\
\text { employment } \\
\text { opportunities }\end{array}$ & 20 & +3 & +60 \\
\hline $\begin{array}{l}\text { Navigation and boat } \\
\text { communication }\end{array}$ & 10 & -2 & -20 \\
\hline $\begin{array}{l}\text { Community up } \\
\text { gradation }\end{array}$ & 10 & +3 & +30 \\
\hline $\begin{array}{l}\text { Commercial area build } \\
\text { up }\end{array}$ & 15 & +3 & +45 \\
\hline Land scape change & 3 & +2 & +6 \\
\hline Transportation facilities & 27 & +5 & +135 \\
\hline $\begin{array}{l}\text { Aesthetic value or } \\
\text { recreation }\end{array}$ & 5 & +2 & +10 \\
\hline \multicolumn{1}{|c|}{ Total } & & & $+\mathbf{2 4 6}$ \\
\hline
\end{tabular}

N. B: Individual Environmental Impact Value $=$ Relative Impact Value * Degree of Impact

Table 7. Total environmental impact estimation

\begin{tabular}{|l|l|c|}
\hline Sector & Total & $\begin{array}{l}\text { Result(EIV) } \\
\sum^{n}{ }_{i=1}(\mathrm{Vi}) \mathrm{Wi}\end{array}$ \\
\hline Ecological & -99 & -3 \\
\cline { 1 - 2 } $\begin{array}{l}\text { Physcio-chemical } \\
\text { Impact }\end{array}$ & -150 & \\
\hline Human Interest & +246 & \\
\hline
\end{tabular}

After observing and estimating all the parameters we are able to identify the Environmental Impact Value (EIV) of our project. The EIV considering both positive and negative, we found -3 (three) negative. On the basis of this result we can say that this project has moderate negative impact on the environment but if we are able to take precautionary measures to eliminate the negative impacts of this project then this project would be a successful one and people get benefits from the project. After considering all the issues we recommend "Bogha Bridge Project" should be constructed. Strict implementation of Environmental Management Plan (EMP) brings the best outcome and success of the project in term of reducing negative environmental impacts of this project. A proper environmental management plan can ensure the environmental sustainability of a project (Ahmad et al., 1994; Daniel et al., 2004). If EMP will implement properly then the negative impacts on environment can be minimized but without EMP the negative impacts on environment of this project will be much more severe that are depicted in the following graphical presentation.

\section{Conclusions}

The summary demonstrates that there is considerable opportunity for the development of this area by the construction of Boga Bridge. The life style of this area's people must be change overnight due to the development of this area by the Boga Bridge. This bridge must be treated as the development pill of this area, especially in the Bauphal, Doshmina and Golachipa area. Although this area may face significant environmental change if this bridge construct; such as: river route change, rise of char land, the depth of river may decrease, river erosion, agricultural land loss, loss of trees, loss of fisheries, jobs at ferry ghat may be lost, public health safety, surface water pollution, air pollution, soil contamination, accidents etc. As a result many local people have to be migrated from these places. After properly evaluation of environmental impact, the environmental impact value was found as " -3 " (negative three), that means this project has some significant negative environmental impact, but with proper implementation of mitigation measures such as dredging, revetment, relocation, tree plantation, digging of pond, cash compensation, provide new jobs, to maintain navigational clearance, provide safe water, good food and sanitation, avoid wastes, cement, chemicals, etc. disposal in water, install plants at safe distance from locality, avoid disposing solid wastes on soil, using personal protective equipment etc. those impact must decrease. This report briefly describe the pre , during and post construction negative impact and its mitigation measures, many alternatives, environmental management plan, monitoring plan 
for ten years, management and monitoring budget which must reduce the environmental impact value. With some negative impact this project has many positive impacts such as generation of employment opportunities, community up gradation, commercial area build up, land scape change, transportation facilities, roadside plantation, aesthetic value or recreation. After all, Boga Bridge is necessary for the economic development of Bauphal, Doshmina and Golachipa region. It also reduces the enormous suffering of transportation of that area's people. After considering the all issue it is strongly recommend that the Boga Bridge should be established.

\section{References}

Ahmed, M. F.; Badruzzaman, A. B. M.; Hossain, M. D. and Rahman, M. 1994. Environmental Management Action Plan, ISBN: 984- 300151- 6 .

Daniel, S.; Tsoulfas, G.; Pappis, C. and Rachaniotis, N. 2004. Aggregating and evaluating the results of different Environmental Impact Assessment methods. Ecological indicators, 4:125-138

Environmental Assessment Report on Padma Multipurpose Bridge Project. 2010. Prepared by the Bangladesh Bridge Authority (BBA) for the Assain Development Bank (ADB), Project Number: 35049.

\section{Acknowledgements}

We would like to express our appreciation to all the people whose effort and input made it possible for this report to carry on to completion. First, our sincere gratitude goes to Water Development Board, Department of Roads and Highways, Bangladesh Bridge Authority and Department of Environment for their valuable advice, guidance and encouragement during the entire process of this report. We express our deep gratitude to the chairman and member of Boga union parishad, Upazila parishad officer in Dumkiupazila and community's people of the study area for their heartiest cooperation throughout the study period.

Krishnamoorthy, B. 2005. Environmental Management. Prentice Hall of India, New Delhi 110001. pp. 62-74.

Kundu, B. R. 2011. Feasibility study of Lebukhali bridge on barisal - patuakhali road (n8).

Huq, M. M. 2002. The Jamuna Bridge: whose benefit and impacts on socioeconomic activity.

Saha, S. K. 2007. Environmental Impact Assessment. AH Development publishing house, New Market, Dhaka. p.165.

Wilson, L. 1998. A Practical Method for Environmental Impact Assessment Audits. Environ Impact Assess Rev., 18: 59-71 